\title{
Ekstremalių situacijų valdymas: ekstremalių situacijų vadybininkų kompetencijų modelio formavimo gairẻs
}

\author{
Arvydas Survila, Andrius Valickas \\ Mykolo Romerio universitetas, \\ Ateities g. 20, Vilnius
}

DOI:10.13165/VPA-15-14-2-08

\begin{abstract}
Anotacija. Vadovaujantis šiuolaikiniu ekstremaliu situacijų valdymo supratimu ir bendruoju tarpdisciplininiu požiūriu i ekstremaliu situaciju valdyma, šiame straipsnyje nagrinejjamos šiuolaikiniam ekstremaliu situaciju vadybininkui reikalingos kompetencijos. Šiuolaikiniame nuolat besikeičiančiame pasaulyje individas, bendruomenè, šalis nuolat susiduria su gausybe pasireiškiančiu arba galinčiu pasireikšti grèsmių. Valstybès, kaip pagrindiniai veikejjai, atsakingi už ekstremaliu situaciju valdyma skirtinguose valstybès valdymo lygiuose, labiausiai suinteresuotos kokybišku ir efektyviu tokiu situaciju valdymu kiekviename valdymo lygyje. Suprasdami ekstremaliu situaciju valdyma tarpdisciplininiu požiūriu, autoriai teigia, kad siekiant sèkmingai suvaldyti grèsmiu pasireiškima ir ju sukeltas pasekmes, skirtingo lygio ekstremaliu situacijų vadybininkai turètu büti kompetentingi, o ju kompetencijos modeli turètu sudarytų dvi pagrindinès sudedamosios dalys: vadybinių žiniu visuma, taikytina ekstremaliu situacijų valdymui, ir lyderyste. Vadybiniu žiniu visuma turètu sudaryti platus skirtingu vadybiniu dalyku kontekstas, kuris igalintu efektyviai valdyti mažinimo, pasiruošimo, atsako ir atkūrimo veiksmus. Ekstremalių situacijų lyderio savybès bütinos veikiant neapibrěžtose situacijose, kurios reikalauja skubiu ir adekvačiu situacijai sprendimu. Tik tokias kompetencijas turintis ekstremaliu situaciju vadybininkas atitiks šiuolaikinius reikalavimus.
\end{abstract}

Raktažodžiai: ekstremaliu situaciju valdymas, ekstremaliu situaciju vadybininko kompetenciju modelis, lyderyste ekstremaliu situacijų valdyme.

Keywords: emergency management, emergency manager's competency framework, leadership in emergency management. 


\section{Ivadas}

Šiuolaikinè visuomenè kasdienèje savo veikloje susiduria su įvairiomis grèsmèmis. Grèsmè - tai potencialios žalos šaltinis valstybei, bendruomenei, gyventojams, taip pat aplinkai, privačiai ir viešai nuosavybei, infrastruktūrai ir verslui. Faktinis galimų grèsmių skaičius pasaulyje yra stulbinantis ir jų sąrašas jokiu būdu nėra baigtinis. Tačiau individas, bendruomenè, regionas, visuomenè susiduria su grèsmėmis, kurių kiekis praktiškai yra ribotas, nes priklauso nuo mūsų genetikos, judèjimo erdvejje, gyvenamosios vietos, veiklos, geografinès padèties ir atsitiktinumo. Fizinè vieta (geografinè padètis) nusako su kokiomis gamtinèmis grèsmėmis galime susidurti. Ekonomika, pramonè, socialiniai, politiniai veiksniai nurodo žmogaus sukurtų (tyčinių, iš anksto apgalvotų, kilusių dèl žmogaus įtakos) grèsmių kilmę. Globalizacija, tarptautinio susisiekimo prieinamumas, globali klimato kaita - visa tai, kas palengvina grésmių pasekmių sklaidą plačioje teritorijoje. Suprantama, kad neįmanoma suplanuoti ar apsisaugoti nuo visų nenumatytų atvejų, todèl didžiausias dèmesys sutelkiamas ị tas grèsmes, kurios sukelia labiausiai nepageidaujamas pasekmes. Ne visos grèsmès, su kuriomis šiandien susiduriame, kyla valstybejje, kurioje gyvename. 2003 m. didžiuliai karščiai Europoje pareikalavo 35000 gyvybių, prieš dešimtmetị cunamis Indijos vandenyne pražudè 300000 žmonių, nes žmonès nesuprato pranešimų apie artėjančią nelaimę. 2011 m. Fukušimos avarija Japonijoje priminè apie branduolinị saugumą. Grèsmès kyla ne tik dèl sunkiai prognozuojamo gamtos poveikio, „dievo valia“ ar dèl avarijų, bet ir kaip sąmoningos asocialios žmogaus veiklos rezultatas. To pavyzdžiu gali būti terorizmas, kuris pastaruoju metu ypač plinta pasaulyje. Pastarujų metų ịvykiai Ukrainoje rodo, kad grèsmes gali kelti ir kai kurių valstybių interesų raiška, peržengianti nusistovejjusias ir tarptautinėmis sutartimis patvirtintas valstybių sienas.

Kaip sutaria daugelis ekstremaliujų situacijų valdymo tyrinètojų, kiekviena iš jų prasideda, pasireiškus žinomai ar nežinomai grèsmei. Kai ịvyksta mažas incidentas, kurio metu žmonès gali būti sužeisti ar žūsta, pastatai ar infrastruktūra sugriaunami ar apgadinami, gyvybiškai svarbūs ryšiai nutrūksta tam tikram laiko tarpui, bendruomenè turi galimybių atsikurti ir po to, galbūt, atlaikyti ir didesnius poveikius. Tačiau ekstremalių situacijų metu žalojantys poveikiai išplinta didesnejje geografinèje teritorijoje, paveikia didesnị skaičių žmonių, pastatų, pramonės įmonių ir daugiau tarpusavyje susietų socialinių komponenčių. Antriniai poveikiai veikia ne tik nelaimès teritoriją, bet gali išsiplèsti ị platesnę teritoriją ir turèti didesnį poveikio mastą logistikai ir ekonomikai.

Taigi, ekstremaliujų situacijų vadybininkai privalo gebèti identifikuoti visas grèsmes: ir tas, kurios labiausiai tikètinos, ir tas, kurios labiausiai niokojančios. Suprantama, kad neimanoma suplanuoti ar apsisaugoti nuo visų nenumatytų atvejų, todèl didžiausias dèmesys turi būti sutelkiamas ị tas grèsmes, kurios sukelia labiausiai nepageidaujamas pasekmes.

Pasaulyje situacija greitai keičiasi, atsiranda vis naujų grèsmių, kurių pasireiškimas gali turèti įtakos visuomenès saugumui. İstaigų, atsakingų už ekstrema- 
lių situacijų valdymą, vadovams ir kitoms suinteresuotoms šalims iškyla poreikis išsiaiškinti ir aiškiau nusakyti, kokiomis savybemis, žiniomis ir gebejjimais turètų pasižymèti ekstremalių situacijų vadybininkai, ypač tada, kai juos reikia priimti ị darbą, kokiais standartais vadovaujantis reikètų sudaryti tokių vadybininkų mokymo programas, kokiais kriterijais remiantis juos būtų galima paaukštinti. Ekstremalių situacijų valdymo mokslininkams kyla klausimas, kokiomis kompetencijomis turi pasižymèti šiuolaikinis ekstremalių situacijų vadybininkas, kad tokios situacijos būtų laiku identifikuotos ir suvaldytos pačiu tinkamiausiu būdu. Pastaruoju metu tampa akivaizdu, kad norint sėkmingai suvaldyti ekstremalias situacijas neužtenka vien tik profesinių kompetencijų, būtina, kad ekstremalių situacijų vadybininkas turètų ir tam tikrų asmeninių savybių ir gebėtų imtis lyderystės reikiamu metu. Todẻl ekstremaliųjų situacijų valdymo vadybininko kompetencijos turi tapti valstybès tarnybos kompetencijų sistemos dalimi.

Taigi šio straipsnio tikslas - pagrịsti ir suformuluoti ekstremalių situacijų vadybininko kompetencijų modelio, kurị galima būtų taikyti, rengiant skirtingo lygmens ekstremalių situacijų vadybininkus, gaires. Straipsnio tikslui pasiekti išsikelti šie uždaviniai: atlikti pagrindinių ekstremalių situacijų valdymo funkcijų bei jų valdymui būtinų profesinių žinių visumos analizę; atlikti lyderystès poreikio ekstremalių situacijų valdyme analizę; suformuluoti ekstremalių situacijų vadybininko kompetencijų modelio gaires. Tyrimo metodas - teoriné prielaidų, lemiančių ekstremalių situacijų vadybininko kompetencijų modelio konfigūraciją, analizè.

\section{Ekstremalių situacijų valdymo ciklas ir vyriausybės funkcijos}

Ekstremali situacija - dèl ekstremaliojo ịvykio susidariusi padètis, kuri gali sukelti staigų didelị pavojų gyventojų gyvybei ar sveikatai, turtui, aplinkai ar padaryti kitą žalą ir ekstremalių ịvykių - nustatytus kriterijus atitinkančių, pasiekusių ar viršijusių gamtinių, techninių, ekologinių ar socialinių ịvykių, kurie kelia pavojų gyventojų gyvybei ar sveikatai, jų socialinėms sąlygoms, turtui ir (ar) aplinkai, valdymas [21]. Ekstremalių situacijų valdymas apima grèsmių pasireiškimo tikimybės ir pasekmès mažinimą arba eliminavimą turint tikslą apsaugoti žmones, pastatus ir jų turinį nuo gresiančių pavojų, naudojantis esamais planais, turimais ištekliais ir mokant žmones. Lietuvos Respublikos civilinès saugos įstatymas apibrèžia civilinę saugą kaip veiklą, apimančią valstybès ir savivaldybių institucijų ir įstaigų, kitu įstaigų, ūkio subjektų ir gyventojų pasirengimą ekstremaliosioms situacijoms, veiksmus joms gresiant ar susidarius, ekstremaliujų situacijų likvidavimą ir jų padarinių šalinimą.

Viešajame sektoriuje didele dalis organizacijų atliekamų funkcijų, personalo ir išteklių skirta šiam tikslui. Taigi, viešajame sektoriuje ekstremalių situacijų valdymo sistema planuoja, kaip geriausiai sušvelninti (sumažinti), pasiruošti (pasirengti), atsakyti (reaguoti) ị numatomus arba netikètai pasireiškusius nepageidaujamus ịvykius, 
katastrofas ir nelaimes ir atsikurti po jų. Šiuolaikiniu supratimu ekstremalių situacijų valdymo ciklą sudaro (1 pav.):

- rizikos ir pavojų mažinimo (švelninimo) procesas;

- pasiruošimas (pasirengimas) artẻjančiam poveikiui (iskaitant tokias veiklos rūšis kaip perspejjimas ir evakuacija);

- atsakas (reagavimas) i ekstremalią situaciją;

- atsikūrimas po ekstremalios situacijos, pavyzdžiui, apgadintų svarbių žmogui pastatų ir infrastruktūros ir kt. atstatymas ar renovavimas.

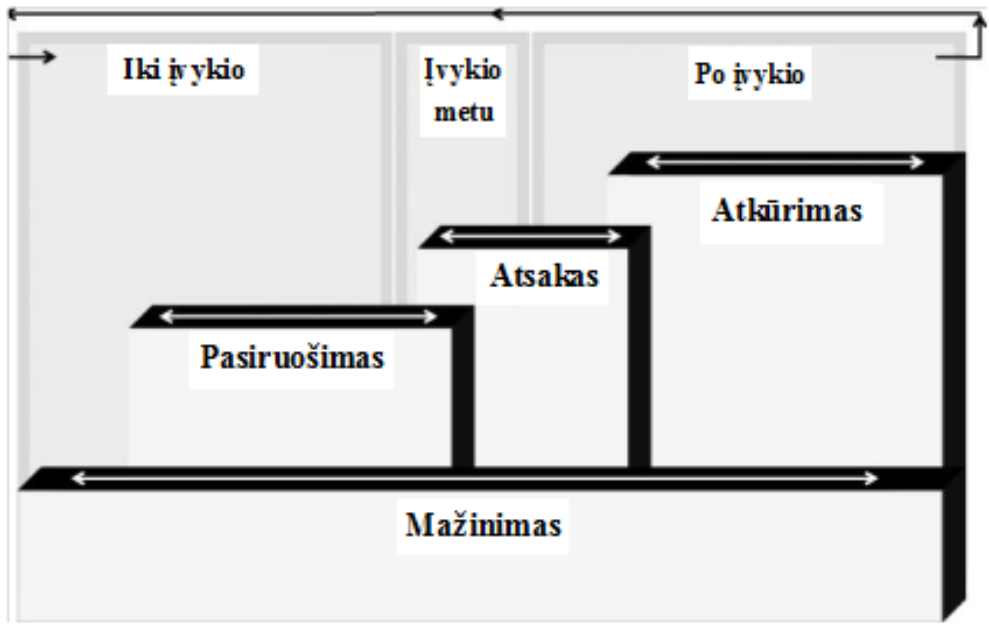

1 pav. Ekstremalių situacijų valdymo ciklas

Mažinimas (švelninimas) laikomas kritiniu ekstremalių situacijų valdymo etapu. Kitos trys ekstremalių situacijų valdymo ciklo funkcijos (pasiruošimas, atsakas ir atkūrimas) vykdomos arba kaip reagavimas ị grèsmes, arba numatant jų pasekmes. Mažinimo priemonėmis siekiama sumažinti grèsmès pasireiškimo tikimybę ir pasekmes prieš įvykstant nelaimei.

Pasiruošimas (pasirengimas) - veiksmų visuma, kurių imamasi, kol ekstremali situacija dar neįvykusi, siekiant užtikrinti adekvatų atsaką jos poveikiui ir palengvinti atsikūrimą patyrus jos pasekmes. Taigi, pasiruošimo funkcija žmonèms, kuriuos gali paveikti nelaimé, suteikia priemones, kurios padidina galimybę apsaugoti save, savo turtą, sumažinti finansinius praradimus ir padèti kitiems. Pasiruošimo ir mažinimo procesais individai, bendruomenès ir šalys siekia sumažinti grèsmės pažeidžiamumą ir tuo padidinti savo atsparumą nelaimei. Deja, nepaisant geriausiai parengtụ ekstremalių situacijų valdymo planų, kompleksiškiausių pasiruošimo programų ir efektyviausių mažinimo priemonių, ekstremalios situacijos vis dèlto įvyksta kasdien, kiekvienais metais. 
Kai grèsmè pasireiškia, individai, bendruomenès, šalys privalo inicijuoti atsako (reagavimo) i ekstremalias situacijas valdymo veiksmus, naudodami savo turimus ribotus materialius išteklius, finansavimą, galimybes ir laiką, kad užkirstų kelią katastrofai. Paprastai ekstremalių situacijų mastas diktuoja ir atsakomųjų veiksmų apimtį. Ekstremalių situacijų valdymo atsako (reagavimo) funkcija siekiama atlikti veiksmus, kurie apribos sužeistụjų, žuvusiųų skaičių ir žalos turtui ir aplinkai mastą. Atsako procesas prasideda iš karto, kai tik tampa aišku, kad ekstremali situacija neišvengiama ir tęsiasi, kol paskelbiama apie jos pabaigą.

Atkūrimo funkcija apima nukentèjusių grąžinimą atgal i , ,normalią“ būklę po ekstremalios situacijos pasekmių poveikio. Atkūrimo veiksmų imamasi paprastai po to, kai baigti atsako veiksmai, kurie gali trukti ir mėnesius ar metus. Atkūrimas yra ekstremalių situacijų valdymo funkcija, kurios metu šalys, bendruomenès, šeimos ir atskiri gyventojai renovuoja, atstato tai, kas buvo prarasta ar sugadinta ekstremalios situacijos metu, ir kartu sumažina panašios situacijos riziką ateityje [9].

Svarbu atkreipti dèmesị ir ị tai, kad: pirma, funkcijos, kurios identifikuotos kaip kritinės ekstremalių situacijų valdymo praktikai: mažinimas (švelninimas), parengtis (pasiruošimas), atsakas (reagavimas) ir atkūrimas, yra procesai, kuriuos, kaip istoriškai susikloste, analizuoja socialiniai mokslai.

Antra, organizacijos, dalyvaujančios ekstremalių situacijų valdyme, yra bendros institucinès struktūros dalys, kurioms priskirtos funkcijos atskleidžia kiekvienos iš jų specializacijos laipsnį (pavyzdžiui, gaisro gesinimas, gynybos pajègų panaudojimas, evakuacija sraigtasparniais, valstybinės tarnybos, turinčios suteikti pirmają pagalbą, - aprūpinti maistu, pastoge, skirti medicinos personalą) [18].

Tai, kas pasakyta, be abejo, apima ir strateginius sprendimus (pavyzdžiui, kaip sukurti santykius tarp organizacijų $[13,20]$ ). Atsižvelgiant ị tai, kad organizacijos tuo pat metu yra ir darbo vietos, jos tampa nustatyto tarpdisciplininio požiūrio ị tarporganizacinių santykių analizę subjektais.

Trečia, bendradarbiavimo ir koordinavimo tarp organizacijų, sistemų ir procesų būtinybė praktikoje apima ne tik tarporganizacinių santykių analizę, bet taip pat ir nestruktūrizuotų ir neformalių formų tarpusavio ryšius tarp skirtingų žmonių grupių ir individų [18].

Ketvirta, ekstremalios situacijos pritraukia dali visuomenès, kuri paprastai yra nuošaliau nuo ekstremalių situacijų valdymo (pavyzdžiui,, žiniasklaida ir savanoriai), o tai, nors ir laikinai, neapibrèžtu pagrindu keičia ekstremalių situacijų valdymo ribas [20].

\section{Ekstremalių situacijų valdymo sistemos hierarchiškumas}

Daugelyje pasaulio šalių, siekiant užkirsti kelią grėsmėms atsirasti, sumažinti arba eliminuoti jų poveiki gyventojams ir turtui, sukurtos ekstremalių situacijų valdymo, arba civilinès saugos, sistemos. Lietuvos Respublikos civilinès saugos ịstatymas civilinę saugą apibrèžia kaip veiklą, apimančią ,valstybės ir savivaldybių institucijų ir įstaigų, kitų įstaigų, ūkio subjektų ir gyventojų pasirengimą ekstrema- 
liosioms situacijoms, veiksmus joms gresiant ar susidarius, ekstremaliujų situacijų likvidavimą ir jų padarinių šalinimą [21].“

„Civilinès saugos sistemos tikslai yra: 1) užtikrinti prevencinių priemonių ekstremaliosioms situacijoms išvengti arba susidarymo galimybėms sumažinti vykdymą ir igyvendinimą; 2) padèti gyventojams, valstybės ir savivaldybių institucijoms ir įstaigoms, kitoms įstaigoms ir ūkio subjektams, gresiant ar susidarius ekstremaliosioms situacijoms, išvengti ar patirti kuo mažiau žalos, išlaikyti rimtį, išsaugoti gyventojų gyvybę, sveikatą, turtą ir apsaugoti aplinką; 3) užtikrinti optimalų valstybės ir savivaldybių institucijų ir ịstaigų, kitų įstaigų ir ūkio subjektų materialinių išteklių panaudojimą, gresiant ar susidarius ekstremaliosioms situacijoms; 4) rengti visuomenę praktiniams veiksmams, gresiant ar susidarius ekstremaliosioms situacijoms, skatinti jos iniciatyvą civilinès saugos srityje ir stiprinti pasitikejjimą civilinės saugos sistemos veikla“" [21].

Šalyse, kuriose yra decentralizuotas valdymas, kur vietos ekstremalių situacijų vadybininkai turi pirminę atsakomybę reaguoti ị ekstremalias situacijas, ekstremalių situacijų valdymo procesas vyksta „žingsnis po žingsnio“. Nukentejjusios bendruomenès vietinè valdžia pirmiausiai stengiasi valdyti pasekmes tol, kol nebepajègia susidoroti savo jègomis. Pasiekus tokị lygmenį, informacija apie susidariusią situaciją perduodama aukštesniam pareigūnui, kuris vèliau nusprendžia, ar kreiptis ị kitą vyriausybini lygmenị pagalbos.

Jei pareigūnas, ị kurị kreiptasi, nusprendžia, kad pagalba būtina, jis pripažįsta, kad ịvyko ekstremali situacija, ir skiria reikalingus išteklius. Jei jis mano, kad esamų jo dispozicijoje išteklių nepakanka ekstremalios situacijos pasekmėms suvaldyti, jis kreipiasi i nacionalinio lygio vadovus papildomos pagalbos. Nacionalinio lygio pareigūnas, paprastai ministras pirmininkas ar prezidentas, privalo, naudojantis pateikta informacija, ịvertinti situaciją ir nuspręsti, ar ịvykis charakterizuojamas kaip nacionalinè nelaimè. Jei paskelbiama nacionalinio masto ekstremali situacija, nacionaliniai vyriausybiniai skirtingų ịstaigų, ministerijų ištekliai bus paskirti nacionaliniam ekstremalių situacijų planui vykdyti. Be to, rezervo pinigai panaudojami ekstremalios situacijos valdymo atsako veiksmams vykdyti.

Lietuvoje „civilinès saugos sistemą sudaro tokie subjektai: 1) Lietuvos Respublikos Vyriausybė (toliau - Vyriausybė); 2) Vyriausybės ekstremalių situacijų komisija; 3) Lietuvos Respublikos vidaus reikalu ministerija (toliau - Vidaus reikalų ministerija); 4) Priešgaisrinès apsaugos ir gelbejimo departamentas prie Vidaus reikalų ministerijos ir jam pavaldžios įstaigos (toliau - Priešgaisrinès apsaugos ir gelbejjimo departamentas ir jam pavaldžios ịstaigos); 5) ministerijos ir kitos valstybès institucijos ir įstaigos; 6) savivaldybių ekstremalių situacijų komisijos; 7) savivaldybių institucijos ir ịstaigos; 8) ūkio subjektai, kitos įstaigos; 9) operacijų centrai; 10) civilinès saugos sistemos pajëgos" " $[21]$.

\section{Vadybinių žinių poreikis ekstremalių situacijų valdyme}

Skirtingų ekstremalių situacijų valdymo sistemos lygių ekstremalių situacijų vadybininkai turi būti išsilavinę ir sugebèti spręsti klausimus ịvairiose srity- 
se. Kiekviename lygyje atliekamas ekstremalių situacijų valdymas pagal anksčiau minètą ciklą ir valdymo efektyvumas bei kokybè kiekviename lygyje užtikrinami, jei tai atlieka kompetentingas ekstremalių situacijų vadybininkas. Ekstremalių situacijų vadybininko kompetenciją galime charakterizuoti dviem pagrindinèmis dimensijomis: profesinių žinių visuma ir lyderyste.

Esminis klausimas formuojant ekstremalių situacijų valdymo vadybininko profesinių žinių visumą yra, kaip ị ją integruoti tinkamiausias disciplinas. Ekstremalių situacijų valdymo pagrindas, iš vienos pusès, yra visuma organizacijų, sistemų ir procesų, kurie yra techniniai, funkciniai ir racionalūs, turintys pagrindinị tikslą sumažinti visų galimų grèsmių tiek gamtinių, tiek žmogaus sukurtų, pasireiškimo žalą, iš kitos pusès, tai motyvacija ir galia, ateinantys iš to, ką galima pavadinti politika. Apskritai, pagrindas glūdi viešajame sektoriuje ir priklauso valstybès vadovybei ir jai pavaldžioms institucijoms, bet taip pat apima ir privataus sektoriaus dalis (pavyzdžiui, draudimo bendrovès) ir savanorius kaip nevyriausybinių organizacijų narius. Taigi, viešosios valdžios institucijoms, atsakingoms už ekstremalių situacijų valdymą, svarbu surasti kompromisą su nepavaldžiomis jai organizacijomis ir kitais žmonėmis (pavyzdžiui, nelaimių aukos, politinès institucijos ir žiniasklaida). Už pagrindinių viešojo ekstremalių situacijų valdymo organizacijų yra kontekstas, kuris turi ịtakos joms ir jos turi įtakos jam [18].

Alexanderis (2004) pasiūlè galimus ekstremalių situacijų planavimo ir valdymo specialistų rengimo programų kokybę ir turinị užtikrinančius standartus, nagrinèjo, ar standartai yra tinkama priemonè spręsti šị klausimą, ir padare išvadą, kad jie padètų užtikrinti palyginamumą, kokybès užtikrinimą ir tarptautinị mokymo suderinamumą [1]. Standartų sukūrimas padètų skatinti tarptautinį mokymąsi, žinių mainus ir jų palyginamumą tarp ekstremalių situacijų darbuotojų. Tai taip pat padètų sukurti visavertę profesiją, kurios gyvybiškai reikia [8].

Plačiąa prasme standartas apibréžtų minimalią mokymo kursų, seminarų ir praktinių užsièmimų, reikalingų užtikrinti pakankamą žinių, patirties, kompetencijos ir iggūdžių visumą ekstremalių situacijų vadybininkui [1].

Teigiama, arba daroma prielaida, kad ekstremalių situacijų valdymas yra tarpdisciplininis, bent jau kalbant apie mokslinių tyrimų metodologiją, ir kad disciplinų integracijos būtinumas yra akivaizdus [22;23]. Yra daug priežasčių manyti, kad ekstremalių situacijų valdymas pats skatina tarpdisciplininį požiūrį. Tarpdisciplininis požiūris linkęs padalinti reiškinius ị atskiras disciplinas ir konkuruojančias teorijas.

Visų skirtingų lygių ekstremalių situacijų vadybininkai privalo turèti būtiną išsilavinimą ir reguliariai turi būti mokomi atremti iššūkius. Mokymo programos turètų būti pritaikytos ir apimti ịvairias sritis, ịskaitant rizikos vertinimą, rizikos valdymą, planavimo ir pasirengimo principus, organizacijos valdymą, kontrolę ir sprendimų prièmimą, tarpinstitucinị bendradarbiavimą, visuomenès informavimą, ryšius su žiniasklaida, streso ir kolektyvinio elgesio valdymą, ekstremalių situacijų mediciną, derybų meną ir vertinimą bei mokymąsi [15]. Sudarant mokymo programas išryškètų jų specifika ir skirtumai, priklausomai nuo to, kokio lygmens ekstremalių situacijų vadybininkus rengiame - vietinio, aukštesnio ar nacionalinio lygmens. 
Tokios mokymo programos turètų būti ịprastų paskaitų, atvejo analizès tyrimų, bendro pratybų scenarijaus kūrimo, vaidmenų modeliavimo ir visos apimties pratybų derinys. Išvardintos mokymų dalys bus sėkmingai iggyvendintos tik tada, kai rizikos, saugumo ir ekstremalių situacijų valdymo klausimus suvoks ir parems nacionalinio ir ES lygmens valdžios institucijų vadovai. Be aukščiausio lygio vadovų paramos noras valdyti ekstremalias situacijas greičiausiai išliks nedidelis daugumoje šalių ir bendruomenių, o dominuos tuo metu aktualūs atrodantys kiti klausimai. Įsipareigojimai turètų apimti tris formas: tinkamą išteklių paskirstymą kiekviename lygmenyje, numatymą kiekvieno asmens dalyvavimą šioje veikoje (pavyzdžiui, dalyvavimo pratybose) ir griežtą ekstremalių situacijų valdymo veiklos kokybės užtikrinimo praktiką [15].

\section{Lyderystė ekstremalių situacijų valdyme}

Akivaizdu, kad ekstremalių situacijų valdymas nėra vien tik rutininė veikla, kai naudojamos iš anksto parengtos schemos ar vykdomos parengtos instrukcijos. Galiojantys teisės aktai patys savaime nesprendžia ekstremalių situacijų valdymo problemų, o valdymą atliekantys asmenys, profesionalių žinių pagrindu, įvykus ekstremaliai situacijai, privalo greitai priimti adekvačius sprendimus ir sugebėti užtikrinti, kad juos vykdytų visuomenè, todèl ekstremalių situacijų vadybininkai privalo būti lyderiai, vadinasi, turèti jiems būdingų savybių.

Mokslininkai pripažista, kad daugelyje organizacijų valdymo sričių vadybines kompetencijas privalo papildyti lyderystès kompetencijos [2]. Tik vadybos ir lyderystès sąveika sukuria prielaidas organizacijų efektyvumui ir veiksmingumui. Šios idejjos taikytinos ir ekstremaliujų situacijų valdyme.

Iškyla klausimas, koks yra vadybos ir lyderystès santykis bei kaip vadyba ir lyderyste gali būti konceptualizuojama viena kitos atžvilgiu? Šiuo požiūriu D. V. Simonetas ir R. P. Tettas (2013) identifikuoja penkis skirtingus požiūrius [25].

Pirmasis iš jų - bipolinis. Jame vadyba griežtai atskiriama nuo lyderystės ir yra suvokiama kaip pastarosios priešybè. Vadybininkai ir lyderiai skiriasi pagal daugelị asmenybès charakteristikų, ịskaitant ir kompetencijas. Vadybininkai siekia tvarkos, stabilumo ir efektyvumo nusistovejjusiose struktūrose, o lyderiai ịkūnija lankstumą, inovacijas, kūrybingumą. Vadybininkų tikslai formuluojami reaguojant ị praeities ịvykius, o lyderių veiksmai yra nukreipti tiesiogiai į nuolat kintančią ir sunkiai prognozuojamą dabarties situaciją ir ị ateitị. Taigi, šiuo požiūriu geri vadybininkai iš esmès negali būti geri lyderiai, ir atvirkščiai.

Antrasis požiūris - unidimensinis [2]. Jame lyderystė yra suvokiama kaip iš esmès tapati vadybai pagal savo formą, procesą ir funkcijas. Tai, ką organizacijoje veikia vadybininkas, negali būti iki galo standartizuota. Vadybininkui visada tenka reaguoti ị situacijas, kai sprendimui priimti trūksta informacijos, kai informacija dvipasmiška, tenka remtis intuicija, dalyvauti organizacijos politikoje, daryti poveiki naudojantis neformaliomis poveikio priemonemis. Taigi realiame pasaulyje, ypač dabartinejje greitai kintančioje aplinkoje, nèra grynos vadybos ar grynos lyderystės. 
Todèl vadybinès ir lyderystès kompetencijos šiuo požiūriu iš esmès nesiskiria ir turètų būti suvokiamos kaip integruota visuma.

Trečiasis požiūris - bidimensinis $[4 ; 19]$. Jame vadyba ir lyderystė yra suvokiami kaip du skirtingi, dažnai vienas kitą papildantys ir sutampantys procesai, turintys įtakos organizacijos efektyvumui ir veiksmingumui. Ir vadyba, ir lyderystė yra aukštesnio lygmens organizacinių procesų dalis, kuri užtikrina organizacijos gyvybingumą dabar ir ateityje. Todèl vadyba ir lyderystè koegzistuoja organizacijoje kaip unikalios veiklos principu sferos. Vadovo, vadybininko ar administratoriaus pareigos sukuria prielaidas lyderystės kompetencijoms ugdyti [3]. Taigi vadyba nèra lyderystès priešingybè, tačiau taip pat vadyba nèra tapati lyderystei.

Ketvirtas požiūris - hierarchinis: vadyba lyderystejje [5;26]. Čia tradiciškai vadovams priskiriamas toks elgesys, stilius ar gebejjimai kaip nurodymų davimas, koordinavimas, kontrolè, planavimas, organizavimas tampa platesnių lyderystès teorijų dalimi, pavyzdžiui, P. Hersey ir K. H. Blanchard'o (1969) situacinè lyderystės teorija ir R. J. House (1971) kelio-tikslo lyderystés teorija [16; 17]. Tai reiškia, kad grynai vadybinès poveikio priemonès ir vadybiniai veiklos principai tampa būtinomis plačiajame lyderystės kontekste siekiant organizacijai svarbių rezultatų.

Penktas požiūris - hierarchinis: lyderystė vadyboje [12]. Lyderyste šiuo požiūriu yra laikoma platesnès vadybos sąvokos ir vadybinès veiklos dalimi. Tai, kiek yra reikalinga lyderystès, lemia darbuotojo pareigos organizacijoje bei konkrečios aplinkybės. Taigi lyderystės kompetencijos šiuo atveju papildo vadybines kompetencijas. Visi penki požiūriai yra apibendrinti ir grafiškai pavaizduoti 2 paveiksle.

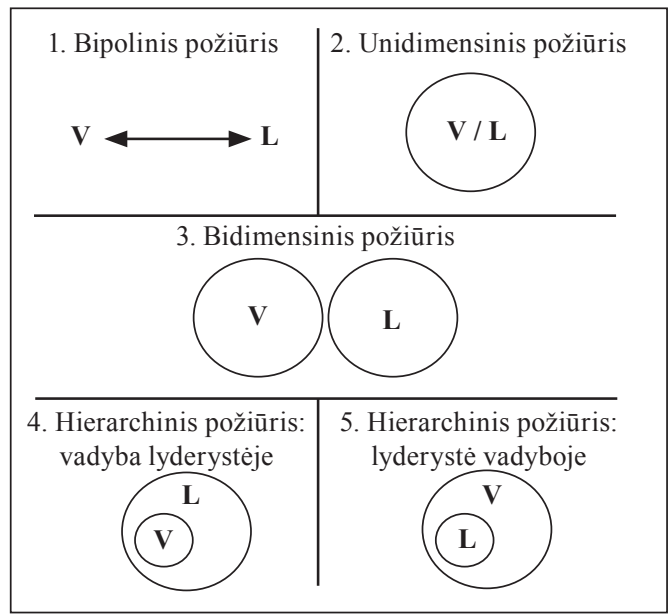

2 pav. Penki požiūriai ị vadybos ir lyderystès santykị (pagal Simonet ir Tett, 2012) [25] (V - vadyba, L - lyderystè) 
Tai, kokios ir kiek reikia lyderystės, priklauso nuo keleto veiksnių: ekstremalios situacijos pobūdžio, aplinkos sąlygų, suinteresuotų pusių, ekstremaliųjų situacijų valdymo stadijos. Taigi vadybos ir lyderystes santykis ekstremalių situacijų atveju labai priklauso nuo konteksto ir konkrečiu aplinkybių.

Mokslininkai akcentuoja skirtingus lyderystės aspektus, būtinus ekstremaliuju situacijų valdyme. Vienas iš svarbiausių - vizijos turèjimas [7]. Vizija nurodo kryptị, ikvepia sekejus, suteikia pasitikejjimo savimi, motyvuoja veikti bei igalina ekstremaliosios situacijos paveiktus asmenis, bendruomenes ar institucijas išeiti iš sudètingos situacijos bei sugrịžti ị normalią būklę. Plati ateities vizija ekstremaliụjų situacijų valdymo atveju turi būti susieta su tokios situacijos paveiktų institucijų ar asmenų poreikiais. Norėdami tai pasiekti ekstremaliujų situacijų valdymo lyderiai privalo ne tik užtikrinti, kad jų veikla būtų legitimi, bet ir igyti bei išlaikyti žmonių pasitikèjimą. Dar prieš kylant ekstremaliai situacijai, būtina turèti tokios situacijos valdymo filosofiją [6]. O tai yra transformacinès lyderystès požymiai. Priešingu atveju sunku būtų tikètis, kad ekstremalioji situacija bus efektyviai suvaldyta ir nepakryps ị chaoso pusę. Ekstremalios situacijos kartais pakeičia supratimą ir apie tai, kas yra normali būklè. Todèl jos gali būti laikomos gera proga jose dalyvaujantiems lyderiams reformuoti institucines struktūras bei peržiūrèti ilgalaikius tikslus, strategijas ir net pačias ateities vizijas [10].

F. Demirozas ir N. Kapucu (2012) teigia, kad ekstremaliosios situacijos pasižymi neapibrèžtumu, neaiškumu, ribotomis galimybėmis prognozuoti situacijos vystymąsi [10]. Taigi veikti tokiose situacijose pagal iš anksto parengtas schemas dažnai būna neįmanoma. Akivaizdu, kad tokiose situacijose būtina mokèti priiminèti sprendimus naudojant racionalius jų priemimo metodus, bet ir pasitelkti riboto racionalumo strategijas, intuiciją, kūrybinį mąstymą. Tačiau tai jokiu būdu nereiškia, kad vadybininkai gali pernelyg supaprastindami vertinti ar interpretuoti tai, kas vyksta ekstremaliujų situacijų atveju [27]. A. Farazmandas (2007) teigia, kad ekstremaliujų situacijų vadybininkui privalo būti būdingas gebejimas „valdyti netikètumą“, kuris remiasi keletu principų: būtina išmokti atmesti viską, kas plaukia iš rutinos, ir tai, ko galima tikètis, reikia reaguoti lanksčiai ir adaptyviai, reikia gebèti ịvertinti, kokios situacijos gali peraugti ị ekstremalias situacijas, reikia turèti pačias naujausias žinias, gebejjimus bei nuostatas ekstremaliujų situacijų valdymo klausimais ir tokių situacijų atžvilgiu, kurios kasdienybejje (nesusiduriant su ekstremaliosiomis situacijomis) gali būti daugumai nesuprantamos, reikia turèti neeilinių gebejjimų naudoti formaliai suteikus igaliojimus ir neformalias poveikio priemones optimaliai panaudoti išteklius [11]. Taigi vadybininkų lankstumas, gebejjimas priimti sprendimus laiku ir mokytis ekstremaliụjų situacijų valdymo yra būtinas.

Ekstremaliujų situacijų valdymo vadybininkui būtini lyderystės gebèjimai, igalinantys efektyviai komunikuoti bei gauti ir naudoti ne tik formaliu būdu igytą informaciją, tačiau ir informaciją, prieinamą neformaliais kanalais. Taigi ekstremaliųu situacijų vadybininkas privalo efektyviai dirbti formaliose ir neformaliose komandose ir tinkluose, kurie apima ịvairias suinteresuotas institucijas, bendruomenes ir 
kitas grupes (politikus, valstybės tarnautojus). Čia sėkmę gali užtikrinti tik gebėjimas bendradarbiauti.

D. McEntire'as ir G. Dawsonas (2007) skiria tris svarbius ryšių palaikymo, komunikacijos ir bendradarbiavimo aspektus ekstremaliujų situacijų valdyme [24]. Pirmiausia jie teigia, kad dar prieš ekstremaliąsias situacijas sukurti ryšiai yra esminiai efektyviam ekstremaliụjų situacijų valdymui. Ekstremaliųų situacijų atveju tarpinstituciniai ir tarpasmeniniai komunikacijos kanalai ir ryšiai nebeturètų būti kuriami, jie turètų būti naudojami. Antra, ekstremaliosios situacijos reikalauja, kad būtų naudojamasi bendra komunikacine infrastruktūra ir suderintomis technologijomis. Ir trečia, organizacijos privalo norèti dirbti kartu. Priešingu atveju jokie formalūs komunikacijos kanalai neveiks. Noras dirbti kartu čia gali būti suprantamas kaip nusiteikimas ir noras padaryti daugiau nei numatyta formaliuose darbo instrukcijose ar organizacijos veiklą reglamentuojančiuose dokumentuose. Lyderystės lyderio nario mainų teorijoje tai yra suvokiama kaip formalių ribų peržengimas, perejjimas ị partnerystès etapą [14].

Taigi apibendrindami galime teigti, kad tam tikros lyderystès kompetencijos turi konstruktyviai papildyti grynai profesines ir vadybines ekstremalių situacijų valdymo vadybininko žinias. Lyderystės kompetencijos turi būti integruotos ị ekstremalių situacijų vadybininko kompetencijų modelį.

\section{Išvados: nepaprastųjų situacijų vadybininko kompetencijų modelio formavimo gairès}

1. Šiuolaikinèje visuomenèje kasdieniame gyvenime nuolat susiduriame su skirtingų grèsmių pasireiškimais, todèl siekdami gyventi saugiau privalome suvokti, iš kur kyla grèsmės, ir išmokti jų pasireiškimus sumažinti, pasiruošti jų pasireiškimams, adekvačiai reaguoti (atsakyti) i juos ir atkurti „normalią“ bendruomenés būseną.

2. Daugelyje pasaulio šalių, siekiant užkirsti kelią atsirasti grèsmėms, sumažinti arba eliminuoti jų poveikį gyventojams ir turtui, sukurtos ekstremalių situacijų valdymo, arba civilinès, saugos sistemos, kurios ekstremalias situacijas valdo hierarchiniu principu: nuo žemiausio administracinio lygmens iki nacionalinio.

3. Valstybė, kaip pagrindinis veikèjas, atsakingas už ekstremalių situacijų valdymą visuose lygiuose, turi užtikrinti kokybišką ir efektyvų ekstremalių situacijų valdymą, t. y. kiekviename lygyje turetti kompetentingus vadybininkus.

4. Siūloma sukurti standartą, kuris apibrèžtų minimalią mokymo kursų, seminarų ir praktinių užsièmimų, reikalingų užtikrinti pakankamą žinių, patirties, igūdžių, visumą ekstremalių situacijų vadybininkui. Tokią žinių visumą turètų sudaryti tokios sritys: rizikos vertinimas, rizikos valdymas, planavimo ir pasirengimo principai, organizacijos valdymas, kontrolè ir sprendimų prièmimas, tarpinstitucinis bendradarbiavimas, visuomenès informavimas, ryšiai su žiniasklaida, streso ir kolektyvinio elgesio valdymas, ekstremalių situacijų medicina, derybų menas ir vertinimas bei mokymasis. 
5. Išvardintos mokymų dalys bus sèkmingai igyvendintos tik tada, kai rizikos, saugumo ir ekstremalių situacijų valdymo klausimus suvoks ir parems nacionalinio ir ES lygmens valdžios institucijų vadovai.

6. Tam tikros lyderystès kompetencijos turi konstruktyviai papildyti grynai profesines ir vadybines ekstremalių situacijų valdymo vadybininko žinias. Lyderystės kompetencijos turi būti integruotos ị ekstremalių situacijų vadybininko kompetencijų modeli.

7. Pagrindinès lyderystės kompetencijos, turinčios tapti ekstremalių situaciju vadybinio kompetencijų modelio dalimi, yra šios: vizijos ir ekstremalių situacijų valdymo filosofijos turejimas, gebėjimas ịgyti bei išlaikyti žmonių pasitikejjimą, pasitelkti riboto racionalumo strategijas, intuiciją, kūrybinị mąstymą, gebẻjimas priimti sprendimus laiku ir „,valdyti netikètumą“, lankstumas, gebėjimas efektyviai komunikuoti, dirbti formaliose ir neformaliose komandose bei tinkluose, bendradarbiauti, peržengti formalias biurokratines ribas ir kliūtis, kai situacija to reikalauja.

\section{Literatūra}

1. Alexander, D. Towards the Development of Standards in Emergency Management Training and Education. In: Disaster Management by Emerald Insight Staff, Emerald Group Publishing Ltd, 2004, 113-122.

2. Alvesson, M., Sveningsson, S. The great disappearing act: difficulties in doing "leadership." Leadership Quarterly, 2003, 14, 359-381.

3. Bass, B. M., Bass, R. The bass handbook of leadership: Theory, research, and managerial applications. NY: Free Press, 2008.

4. Bennis, W., Nanus, B. Leaders: Strategies for taking charge. NY: Harper \& Row, 1985.

5. Boal, K. B., Hooijberg, R. Strategic leadership research: Moving on. Leadership Quarterly, 2000, 11, 515-549.

6. Boin, A., T'Hart, P. Public Leadership in Times of Crisis: Mission impossible? Public Administration Review, 2003, 63, 544-553.

7. Boin, A., T'Hart, P., Stern, E., Sundelius, B. The Politics of Crisis Management: Public Leadership Under Pressure. New York: Cambridge University Press, 2005.

8. Crews, D.T. The Case for Emergency Management as a Profession“, Australian Journal of Emergency Management, 2001,Vol 16, No. 2, 23.

9. Coppola, Damon P. Introduction to International Disaster Management. Boston: Butterworth-Heinemann, 2011.

10. Demiroz, F., Kapucu, N. The Role of Leadership in Managing Emergencies and Disasters. European Journal of Economic and Political Studies, 2012, 5 (1), 91-101.

11. Farazmand, A. Learning from Katrina Crisis: A Global and International Perspective with Implications for Future Crisis Management. Public Administration Review, 2007, 67, 149159 .

12. Finkelstein, S., Hambrick, D. C. Strategic leadership: Top executives and their effects on organizations. St. Paul, MN: West, 1996.

13. Gissing, A., Keys, C., and Opper, S. Towards Resilience Against Flood Risks. Australian Journal of Emergency Management, 2010, Vol. 25(2), 39-45. 
14. Graen, G. B., Uhl-Bien, M. The Relationship-based approach to leadership: Development of LMX theory of leadership over 25 years: Applying a multi-level, multi-domain perspective. Leadership Quarterly, 1995, 6 (2), 219-247.

15. Hart, P., Sunkelius, B. Crisis Management Revisited: A New Agenda for Research, Training and Capacity Building Within Europe“, Cooperation and Conflict, 2013, DOI: 10.1177/00108367134857112013 48: 444 originally published online 7 June 2013.

16. Hersey, P., Blanchard, K. H. Life cycle theory of leadership. Training and Development Journal, 1969, 23(5), 26-34.

17. House, R. J. A path goal theory of leader effectiveness. Administrative Science Quarterly, $1971,16,321-339$.

18. Ingham, V., Hicks, J., Mir Rabiul Islam, Manock, I., Sappey, R. An Interdisciplinary Approach to Disaster Management, Incorporating Economics and Social Psychology, 2012, Vol 6, No. 5. 93-107. http://www.SocialSciences-Journal.com.

19. Yukl, G., Lepsinger, R. Why integrating the leading and managing roles is essential for organizational effectiveness. Organizational Dynamics, 2005, 34, 361-375.

20. Lindell, M. K., Prater, C. and and Perry, R. W. Introduction to Emergency Management, Hoboken, New Jersey: John Wiley and Sons, 2007.

21. Lietuvos Respublikos civilinès saugos įstatymas. Valstybės žinios, 2009, Nr. 159-7207.

22. McEntire, D. A. The Importance of Multidisciplinary and Interdisciplinary Research on Disasters and for Emergency Management. In: D. A. McEntire (Ed.), Disciplines, Disasters and Emergency Management,. Springfield, Illinois: Charles C. Thomas, 2007, 3-14.

23. McEntire, D. A., and Smith, S. Making sense of consilience: Reviewing the findings and relationships among disciplines, disasters and emergency management. In D. A. McEntire (Ed.), Disciplines, Disasters and Emergency Management. Springfield: Charles C. Thomas, 2007, 320-336.

24. McEntire, D. A., Dawson, G. The Intergovernmental Context. In: Waugh, William L. Jr., and 25. Kathleen Tierney (eds.). Emergency Management: Principles and Practice for Local Government. Washington DC: ICMA, 2007, 57-70.

25. Simonet, D. V., Tett R. P. Five Perspectives on the Leadership - Management Relationship: A Competency-Based Evaluation and Integration. Journal of Leadership \& Organizational Studies, 2013, 20(2), 199-213.

26. Uhl-Bien, M., Marion, R., McKelvey, B. Complexity leadership theory: Shifting leadership from the industrial age to the knowledge era. Leadership Quarterly,2007, 18, 298-318.

27. Weick, K., Sutcliffe, K. Managing the Unexpected: Resilient Performance in an Age of Uncertainty. San Francisco: Jossey Bass, 2007.

\section{Arvydas Survila, Andrius Valickas \\ Emergency Management: Guidelines for Emergency Manager's Competency Model Formation}

\section{Abstract}

On the grounds of contemporary understanding of emergency management and basing on the general interdisciplinary approach, the article examines competencies necessary for nowadays emergency managers. In the contemporary changing world, individual, community and the state permanently encounter a variety of threats and possible threats. The states, as the main interested parties, responsible for emergency management on different levels of 
management, are most interested in qualitative and effective management of such situations on all the levels. Using interdisciplinary approach towards 'extreme situations' management, the authors state that in order to successfully manage the threats and the consequences raised by them, different levels of emergency managers have to be competent and the competency model applied to them must be composed of the main two components: the whole of managerial knowledge and leadership skills. Managerial knowledge should be composed of a wide range of managerial subjects relevant to emergency situations, which would enable to effectively manage the situations in the whole range of possible situation. Emergency leadership skills are important in undefined situations, requiring immediate and adequate decisions. Only the managers possessing such competencies will correspond to contemporary requirements and will be able to manage them properly.

Arvydas Survila - Mykolo Romerio universiteto Politikos ir vadybos fakulteto Vadybos instituto docentas, matematikos mokslų daktaras.

E. paštas arvydas.survila@mruni.eu

Andrius Valickas - Mykolo Romerio universiteto Politikos ir vadybos fakulteto Vadybos instituto docentas, socialinių mokslų daktaras.

E.paštas avalickas@mruni.eu

Arvydas Survila, Doctor of Mathematics, Department of Management, Faculty of Politics and Management, Mykolas Romeris University, Associate Professor.

E-mail: arvydas.survila@mruni.eu

Andrius Valickas, Doctor of Social Sciences, Department of Management, Faculty of Politics and Management, Mykolas Romeris University, Associate Professor.

E-mail: avalickas@mruni.eu

Straipsnis įteiktas redakcijai 2014 m. lapkričio mèn.; recenzuotas; parengtas spaudai 2015 m. gegužès mèn. 